\title{
Critical Writing: Bertold Brecht's The Caucasian Chalk Circle (Der Kaukasische Kreidekreis, 1944)
}

\author{
Antonius Herujiyanto \\ English Language Education Study Program, Sanata Dharma University, Yogyakarta \\ anton.herujiyanto@gmail.com
}

\begin{abstract}
Having read and had discussion on outstanding literary works of European writers, there comes a conviction that the works have indeed played an important role in changing what so-called the course of literary in Europe. They are, indeed, masterpieces which are not simply ones that are done with very great skill. There are, indeed, several aspects to consider before determining what a literary masterpiece is - to mention one, its integrity in the light of social conditions and of aesthetics. A better understanding of the works may be achieved, among others, by looking into and situating them in their historical and cultural context. Scrutinizing and analyzing Brecht's The Caucasian Chalk Circle is an experience of developing a kind of heightened critical and analytical faculty. It can be poited that the two main characters of the play, Grusha and Azdak, are made use by Brecht to practice his epic theater in general, and his Verfremdungseffekt in particular. They are too "estranged" for us to be able to accept them as heroes. Brech, however, manages to highlight the vitality of his central characters.
\end{abstract}

Key words: outstanding, aesthetic, cultural context, Verfremdungseffek

The need to act the new drama correctlymore important for the theatre than for the

drama-is weakened by the fact that the theatre can act everything; it "theatricalizes" everything. (Brecht, 1931)

\section{Introduction}

This paper is an attempt to critically look into Brecht's The Caucasian Chalk Circle. ${ }^{1}$ The emotive effects, main characters and certain dimensions of the so-called Brechtian Theater as embodied in the play are the focus of this study and within its scope is drama as text. The decision of favoring drama as text is simply due to practical reasons.

The Caucasian Chalk Circle is one of the "classics" of the Brechtian repertoire. His other plays which have most established his reputation internationally are The Life of Galileo (Leben des Galilei) (first version,
1938); Mother Courage and Her Children (Mutter Courage und ihre Kinder) (1939); Mr. Puntila and His Man Matti (Herr Puntila und sein Knecht Matti) (1941); and The Good Woman from Setzuan (Der gute Mench von Sezuan (1939-41).

Understandably, it is not easy to describe the principles of the Brechtian Theater or to define what Brechtian theater is, especially that-like anything else-there is no such a thing as lasting indefinitely. A twenty year old Brecht, for example, is not the same as a thirty five year old Brecht; Brecht's opinion on theater in 1948 could be his "only past opinion" when he was in 1955, one year before his death on 14 August 1956. Of course, instead of saying everybody changes, we may also say that everybody develops. It is understandably that in the Preface of Brecht on Theater, John Willett writes that it is necessary to give and set Brecht's notes and theoretical writing in chronological order to see how Brecht's ideas evolved, gradually 
forming into a certain aesthetic; that it is also important to look into Brecht's endless working and reworking, his nagging at a particular notion until it could be fitted in: the progress from an embryo to an often very differently formulated final concept as well as the amendments and his after-thoughts (Brecht, 1986: xiii).

Actually, much has been said and written about Brecht. His importance as a playwright is universally recognized. Inspired by ancient tradition, he nevertheless developed a new technique for his theater, taking practical steps toward refunctioning (Umfunktionierung) the so-called old theater. As a result, not only did he develop a new technique, but also introduced certain terms. In Ousby's The Cambridge Guide to Literature in English, for example, Brecht is mentioned that he coined the word Verfremdung (alienation) to carry his meaning, and that his using of "alienation effects influenced all the major political writers of the post-war English theater from John Arden ... to ... Howard Brenton" (18).

Brecht's fundamental technique or rather his alienation effect (Verfremdungseffekt) is not, admittedly, as simple as what one might first think: reminding the spectators that they are watching a play; making the stage machinery visible; having the characters talk or sing directly to the audience, and so on. Besides, Verfremdungseffekt is only one aspect of what they call Brecht's theater or Epic theater. In order to know him better is, unavoidably, to look deeper into all aspects of Epic theater.

The theories on which this study is built, however, are those of "Brecht's journeys," from 1918 up to 1956, and particularly those of his "Kleines Organon für das Theater" or "A Short Organum for the Theater" which he wrote from 1947 to 1948. Realizing that to follow through all of "Brecht's journey" can mean falling into the trap of Brecht's inconsistencies and ending up with simply following-as The Cambridge Guide puts it- "The point can be grasped without theory. It cannot be grasped from the theory alone ..." (187), this study will take the compromising path: taking
Brecht's theory to a certain extent and using his own practicing a form of theater which is "naïve" and at the same time addressing itself to the audience's capacity for reflection. This study will only deal with the emotive effects, some dimensions of what so-called Brechtian theater and the main characters in his The Caucasian Circle Chalk.

\section{Synopsis}

The Caucasian Chalk Circle (Der Kaukasische Kreidekreis) consists of one "Prologue" and five Acts ("The Noble Child," "The Flight into the Northern Mountains," "In the Northern Mountains," "The Story of the Judge, and "The Circle Chalk"); narrative chorus of three or four singers in unrhymed irregular verse; and, twelve songs, of which four sung by the singers. There are more than 30 characters in the play. Two of the main characters are Grusha Vashnadze and Azdak.

The play-written in 1944-5-is a story of young Georgian girl, Grusha, who saves the infant child of a tyrannical governor during an insurrection or rather a rebellion. This story of Grusha and the "high-born child" is made into a play within a play-the scenes are preceded by a scene set in the contemporary world about what may be called "The Fight over the Valley" where two collective farms from Georgia in the former Soviet Union are in dispute about which one has the better claim to a valley.

This simple story of the playsuperficially influenced by the Communist moral-seems to be sufficient in itself: first, demonstrating the principle that greater productivity constitutes a better claim to the valley than traditional rights of possession and second, when the real mother disputes possession of the child with Grusha before the judge Azdak, the verdict goes in Grusha's favour because she alone has shown a true motherly nature and it is politically irrelevant. The final moral is that both valley and the child should go to whoever serves them best.

To be more explicit, anyway, the play is set in feudal Georgia, before the invention of firearms. The prelude shows two Soviet 
collective farms meeting in 1945 to decide which should have a certain valley. They are told the story which constitutes the play proper: The Governor of a Georgian city is overthrown and killed by a nobles' revolt. His wife flees, leaving her baby son behind. Grusha, a servant girl, takes him and look after him; she escapes to her brother's in the mountains, where she has to marry a supposedly dying peasant in order to give it a name and a status. When the revolt ends the Governor's wife sends troops to fetch Grusha and the child back to city, and sues for the child's return.

With the beginning of the fourth Act the story flashes back to the day of the revolt to trace the disreputable career of the "two faces-judge" Azdak. He is, in fact, a tramp-like village scoundrel whom the rebellious soldiers appoint him judge. In the last Act he tries the case, and settles it by reversing the old test of the Chalk Circle: the child is given to Grusha because she cannot bear the traditional tug-of-war which is supposed to end in the child's being drawn out of the circle by maternal attraction. At the same time he gives Grusha a divorce so that she can return to her soldier fiancé.

\section{Brecht's Theater Theory}

Actually the basis of Brecht's theoretical writing can be seen in his Brecht on Theater, especially in paragraph 75 of his "Kleines Organon" where he declares his war against the orthodox theater; he is not happy at all with what so called the pretentious German classical stage (Brecht, 1986: 204):

And here once again let us recall that their task is to entertain the children of the scientific age, and to do so with sensuousness and humour. This is something that we Germans cannot tell ourselves too often, for with us everything easily slips into the insubstantial and unapproachable, and we begin to talk of Weltanschauung when the world in question has already dissolved. Even materialism is little more than an idea with us. Sexual pleasure with us turns into marital obligations, the pleasures of art subserve general culture, and by learning we mean not an enjoyable process of finding out, but the forcible shoving of our nose into something. Our activity has none of the pleasure of exploration, and if we want to make an impression we do not say how much fun we have got out of something but how much effort it has cost us.

Admittedly, many theaters in the world (even up to now) are influenced by Aristotle who emphasized the universality and unity of the tragic action, and the identification of spectators and hero in empathy which produces a "catharsis" of emotions: the designs on the spectators' emotions tend, undoubtedly, to prevent the very spectators from using their head; they are drawn into the "plot" and urged to identify themselves with the characters. In paragraph 26 of his "Kleines Organon," Brecht writes (Brecht, 1986: 187):

For such an operation as this we can hardly accept the theatre as we see it before us. Let us go into one of these houses and observe the effect which it has on the spectators. Looking about us, we see somewhat motionless figures in a peculiar condition: they seem strenuously to be tensing all their muscles, except where these are flabby and exhausted. They scarcely communicate with each other; their relations are those of a lot of sleepers, though of such as dream restlessly because, as is popularly said of those who have nightmares, they are lying on their backs. True, their eyes are open, but they stare rather than see, just as they listen rather than hear. They look at the stage as if in a trance: an expression which comes from the Middle Ages, the days of witches and priests. Seeing and hearing are activities, and can be pleasant ones, but these people seem relieved of activity and like men to whom something is being done. This detached state, where they seem to be given over to vague but profound sensations, grows deeper the better the work of the actors, and so we, as we do not approve of this situation, should like them to be as bad as possible. 
He also says in paragraph 27, how wretched stuff such as a few pieces of cardboard, a little miming, a bit of text like those of the theater folk can move the feelings of the audience amazingly. According to Brecht, the orthodox theater seems morally and intellectually degrading because it makes it harder for the spectators to understand the world in which they really live. In his The Theatre of Bertolt Brecht, John Willett writes "even the world of the past becomes falsified when it is presented to the emotions in this way; psychologically, the classics then come to be played in fancy dress" (170). Concerning this, in paragraph 12 of his "Kleines Organon" Brecht says, “... Our theatres no longer have either the capacity or the wish to tell these stories, even the relatively recent ones of the great Shakespeare, at all clearly: i.e. to make the connection of events credible" (Brecht, 1986: 183).

Then, again in paragraph 34, Brecht says, “ ... The feelings, insights and impulses of the chief characters are forced on us, and so we learn nothing more about society than we can get from the 'setting'." Indeed, it is too much of his bitterness that in paragraph 29 of his "Kleines Organon" Brecht feels that he must write, "That is the sort of theatre which we face in our operations, and so far it has been fully able to transmute our optimistic friends, whom we have called the children of the scientific era, into a cowed, credulous, hypnotized mass" (Brecht, 1986: 188-189).

In his "Schwierigkeiten des epischen Theaters" or "The Epic Theater and its Difficulties," Brecht says that what the audience sees in fact is a battle between theater and play: the most important thing is not the play's effect on the audience but its effect on the theater. The goal is how the theater manages to work out the style of production, a style that can lend new force to a whole section of the theatrical repertoire. It is-Brecht says further-"the epic theatre is the theatrical style of our time" (Brecht, 1986: 22-23).

Explaining the principles of the epic theater, Brecht posits:
To expound the principles of the epic theatre in a few catch-phrases is not possible. They still mostly need to be worked out in detail, and include representation by the actor, stage technique, dramaturgy, stage music, use of the film, and so on. The essential point of the epic theatre is perhaps that it appeals less to the feelings than to the spectator's reason. Instead of sharing an experience the spectator must come to grisps with things. At the same time it would be quite wrong to try and deny emotion to this kind of theatre. It would be much the same thing as trying to deny emotion to modern science (Brecht, 23).

The word "epic" is actually an Aristotelian term for a form of narrative that is "not tied to time," whereas a "tragedy" is bound by the unties of time and place (See, Aristotle, Poetics (2), 5,4 and Schumacher 160-165). ${ }^{2}$ The basic meaning of "epic" even in Brecht's use of the term is "a sequence of incidents or events, narrated without artificial restrictions as to time, place or relevance to a formal 'plot'" (Willett 171). Brecht, in his "The Modern Theatre Is the Epic Theatre," writes that the modern theatre is the epic theatre and shows certain changes of emphasis as between the dramatic and the epic theatre (Brecht, 1986: 37):

\begin{tabular}{|l|l|}
\hline \multicolumn{1}{|c|}{ DRAMATIC THEATRE } & \multicolumn{1}{c|}{ EPIC THEATRE } \\
\hline Plot & Narrative \\
\hline $\begin{array}{l}\text { implicates the spectator in a } \\
\text { stage situation }\end{array}$ & $\begin{array}{l}\text { turns the spectator into } \\
\text { an observer, but }\end{array}$ \\
\hline $\begin{array}{l}\text { wears down his power for } \\
\text { action }\end{array}$ & $\begin{array}{l}\text { arouses his power of } \\
\text { action }\end{array}$ \\
\hline provides him with sensations & $\begin{array}{l}\text { forces him to take } \\
\text { decisions }\end{array}$ \\
\hline experience & picture of the world \\
\hline suggestion & argument \\
\hline $\begin{array}{l}\text { instinctive feelings are } \\
\text { preserved }\end{array}$ & $\begin{array}{l}\text { brought to the point of } \\
\text { recognition }\end{array}$ \\
\hline $\begin{array}{l}\text { the spectator is in the thick of } \\
\text { it, shares the experience }\end{array}$ & $\begin{array}{l}\text { the spectator stands } \\
\text { outside, studies }\end{array}$ \\
\hline $\begin{array}{l}\text { the human being is taken for } \\
\text { granted }\end{array}$ & $\begin{array}{l}\text { the human being is the } \\
\text { object of the inquiry }\end{array}$ \\
\hline he is unalterable & $\begin{array}{l}\text { he is alterable and able } \\
\text { to alter }\end{array}$ \\
\hline eyes on the finish & eyes on the course \\
\hline
\end{tabular}




\begin{tabular}{|l|l|}
\hline one scene makes another & each scene for itself \\
\hline Growth & montage \\
\hline linear development & in curves \\
\hline evolutionary determinism & jumps \\
\hline man as a fixed point & man as a process \\
\hline thought determines being & $\begin{array}{l}\text { social being determines } \\
\text { thought }\end{array}$ \\
\hline feeling & reason \\
\hline
\end{tabular}

Indeed, in the new system, it is clearly seen how Brecht emphasizes the "direct, didactic" aspect of the text; the theater is to be a "theater for instruction"; "Feeling" is opposed to "Reason." Brecht, then, concludes, "Thus to develop the means of entertainment into an object of instruction, and to change certain institutions from places of amusement into organs of public communication" (Willett, 1959: 174).

From the table above, we can see that the picaresque principles are "narrative" rather than "plot," and "each sense for itself." The term "montage," however, is not a new thing (See also Counsell 82-111). As we know, montage was a key concept in many areas of early twentieth-century art such as film, photography, printing. This concept entails juxtaposing disparate images so that each informs and qualifies the other.

As we can see from the table above, there are many new things which change the meaning of "epic": not only do they exclude all idea of entertainment, but also rule out both the traditional conceptions of "catharsis" and "empathy."

What is meant by "epic methods" are, then, the "means of breaking the magic spell, of jerking the spectator out of torpor and making him use his critical sense." His new principle is called "der Zeigende gezeit wird" meaning that the process of showing must itself be shown: presenting songs and subtitles as a deliberate means of interrupting the play; showing the actual mechanics of the work, the musicians and the lights which are accompanied by a deliberate breaking of the tension and disillusionment of the actor; and making sure that the actor must not just sing but show a man singing (Willett, 1959: 174).
Brecht also introduces the term "Gesten" meaning that it is the actor's business not to express feeling but to "show attitudes." The idea of "gestus" is in fact at once gesture and gist, attitude and point: one aspect of the relation between two people, studied singly, cut to essentials and physically or verbally expressed. As about the fragmentary, meaning the episodic style of acting, Brecht explains that it is meant to show a man not as a consistent whole, but as a contradictory, ever-changing character whose unity comes "despite, or rather by means of, interruptions and jumps" (Willett, 1959: 175).

In his essay "Verfremdungseffekte in der chinesichen Schauspielkunst," Brecht discusses his famous concept of Verfremdung, or alienation and mentions the traditional Chinese acting style as a model for actors in epic theater, who seek to make the spectator think about their work by making it "strange." So, as the bourgeois theater presents events as universal, timeless, and unalterable; the epic, or "historicing," theater uses Verfremdung to render even everyday events "remarkable, particular, and demanding inquiry" (Brecht, 1986: 96-97, also see Carlson 385).

Brecht's term Verfremdungseffekt or alienation effect implies two things: first, the breaking of the emphatic link between actor and spectator, and secondly the contradiction he effects between Concrete actor and Abstract character. In other words, it refers both to the separation of actor from character, or any of the Concrete/Abstract binaries, and to the audience's resulting disengagement with the locus. So, the aim of this technique, known as the alienation effect, is to make the spectator adopt an attitude of inquiry and criticism in his approach to the incident (Brecht, 1986: 136).

One of the problems in dealing with Verfremdungseffekt is that we need to mention the other aspects of Brecht's epic theater. So it is unavoidable-now and then-dealing also with those of narrative, making the spectator an observer and arouses his will to action, calling for decisions and a world outlook, argument, the spectator is taught, man is a subject of investigation, 
interest in the course of action, every scene is independent, montage, Gesamkunstwerk (the 'integrated' or 'total[ised]-artwork), the Gestic Split, and even the so-called theater for the Scientific Age, etc.

The various elements of epic theory which Brecht writes in his "Kleines Organon für das Theater" or "A Short Organum for the Theater" may then be summed up: the historizing of the present; the Verfremdungseffekt; the actor's distance from his role; the division of the action into individual and dialectically opposed episodes (each with its basic Gestus); and the separation of the various arts of the drama for similar mutual estrangement.

\section{Discussion}

Admittedly, theory and practice do not often work hand in hand. In his The Caucacian Circle Chalk, however, Brecht has tried to apply his theater theories althoughto a certain extent-we can feel "catharsis" quite strongly emerging from Grusha. His consistency with his theories may be seen through his techniques of exposing the role of the singer as well as the characters: breaking the magic spell, of jerking the spectator out of torpor and making him use his critical sense and indirectly convincing the audience that he or she is watching a play. This is done, once again, by presenting songs and sub-titles (of each Act) as a deliberate means of interrupting the play.

Brecht, anyway, wrote the play in the early and middle forties when he was in California. $^{3}$ It was originally written for the actress Luise Rainer, since she had played the role equivalent to Grusha's in Klabund's Circle of Chalk-an anonymus Chinese play of about 1300 A.D. - and so, without which Brecht's The Caucacian Chalk Circle would probably never have been thought of (Bentley 9). It is, therefore, a kind of naïveté to look into the introductory of the play-about what socalled the "Fight over the Valley"-as the account of contemporary history of Soviet agricultural collectivisation. As we know, its real history is one of coercion and resistance. The fiction-that the play within the play is based on an old folk epic-may only create a framework of convention: the simplifications of the parable-like tale of Grusha and Azdak, and no more. This can also be seen in the play itself: about how the farmers relinquish and give up the valley, their home, after only the mildest protests. It is weird especially that for most farmers in the world, the loss of their homelands is a matter of life and death and on top of that, for many Russian farmers, it means being thrown away into cattle-trucks and forcibly deported to some distant corner of the Soviet territory. They should not have given up their land so easily. It is not surprisingly, therefore, that the so-called "utopian prologue" is often judged unconvincing wherever it is performed; it simply has to be omitted in any Russian production (Speirs, 1987: 161).

Given that Brecht makes use of naïve dramatic forms, we can, indeed, expect that The Caucasian Circle Chalk is rich in emotive effects. The main focus of the play's emotional appeal is, of course, the maid Grusha. During the panic of a palace revolution, for example, she is just so calm deciding to take responsibility for the baby; she is also presented in an attractive light in two scenes where she is first teased an then proposed to by the soldier Simon Shashava. Her attraction resides in a directness and honesty of feeling that seems to be a beneficial consequence of the fact that she is rather naïve and not very quick on the uptake. On the other hand, she is not lacking in good sense especially when she makes clear to Simon that she is against any unnecessary heroics as we can see towards the end of Act 3 (III, 169):

SIMON. I see a cap in the grass. Is there a little one already?

GRUSHA. There is, Simon. There's no keeping that from you. But please don't worry, it is not mine.

When we look back into Act 1, particularly towards its end, we can see how Grusha finally picks up the abandoned child and goes off with it in search of a refuge. The accumulated emotive effects may be felt, starting right from the preceding scenes: how the child's mother simply forgets about her own baby; her first concern is about what 
clothes she will take with her and then her own safety; how the other servants, including the child's nurse, Natella Abashvili, are ruthless in putting their own interest first and simply abandoning the child to its fate rather than risk being caught with a child whom the new masters will certainly want to kill; how a group of soldiers carry in on the point of a lance the severed head of the governor and impale in above the palace gate. It even seems that Grusha too, after wrapping the child, is going to follow the advice and example of other servants. However, just as she is about to leave, she hears the childthrough the voice of the singer-"speaking" to her and asking for her help in (I, 138): “... woman ... help me ... don't you know woman, that she who does not listen to a cry for help ... will never hear the gentle call of a lover ...."

Next, we are exposed to how Grusha spends the night looking after the child while around her the city is filled with flames and the tumult of civil war: "... she watched the soft breathing, the little fists ... till towards morning ...."

Actually the emotional bond formed between Grusha, the child and the audience in the first act is strengthened as the action unfolds. During her journey to the mountains, for example, she encounters one danger after another, each situation throwing her human worth into ever clearer relief. She has to pay almost a half of a week's wages from her very little money to buy milk for the child and even willing to pay an even more outrageous sum just to have some shelter for the baby at night from the icy winds coming down from the Janga Tau glacier-Brecht strengthens this emotion by at the same time exposing the heartlessness of a pair of aristocratic women refugees.

Brecht, however, wants to point out that the relationship between Grusha and the child is not one of simple saintliness (II, 143): being exhausted, she decides to leave the child at the door of a peasant cottage. Once she sees that the child has been carried into the cottage, Grusha sets off in the opposite direction, laughing of her ploy and happy to be free of a burden.
So, once again, Brech wants to show that Grusha still has interests of her own, especially that she has another, older attachment, to the soldier Simon. In II, 143 she says, "... now I must turn around. My sweetheart the soldier might be back soon, and suppose he didn't find me? You can't ask that, can you?" This is, in fact, the follow up of what has happened before (I, 133) when she wants to be free to find Simon when the war is over:

Simon Shashava, I shall wait for you.

Go calmly into battle, soldier

The bloody battle, the bitter battle

From which not everyone returns:

When you return I shall be there.

\section{I shall wait until the last soldier has returned \\ And longer. \\ When you come back from the battle}

when you return, when you return

You will be able to say: It is just as it was.

It is evident, nevertheless, that she can only bring herself to leave the child because it seems in the child's best interests. She is, however, deeply saddened at the loss of the child ... . Grusha has, in the end, hardly gone a few steps, and ... flees in panic back to the cottage ( II, 146).

Brecht also seems to use the conventional dramatic suspense in the play when he makes Grusha adopt the child by substituting rags for its fine linen and baptizing it with glacier water (II, 149); she also has to risk both their lives crossing a primitive bridge with rotten boards and one broken guide rope over a mountain chasm (II, 151).

Brecht produces a kind of shock when he suddenly "leaves" the story of Grusha entirely only in order to introduce the story of the judge Azdak through the singer in Act 4. Here we can see clearly Brecht's application of Montage and Verfremdungseffekt.

From Azdak's first speech, we can also feel how Brecht introduces the character of 
Azdak which stands in strange contrast to Grusha's. Azdak is a thief, a time-server, a coward, who by a lucky accident is raised during the insurrection to a position of authority. His life is spent in careful adaptation to society's moral standards, going along with the tide, and keeping an eye on the main chance. He is a standing affront, and at the same time a standing reminder of the questionable values on which society is based. There is nothing that can properly be called a self in Azdak, nothing consistent or foreseeable in his actions. He is, in fact, insulting and generous, preposterous and humble, ignorant and wise, blasphemous and pious.

In Act 5, "The Chalk Circle," we may see how Grusha and Azdak are confronted with one another: the disruptive, ambiguous underminer and the calm, shrewd, motherly girl who would rather die than forego her humanity. Azdak is called to try the case in which the real mother of the child, the wife of the former governor of the province, claims possession of her son. By a fortune turn of events, the same Grand Duke whose life Azdak saved earlier on has now returned to power, and thus Azdak's contemptible promise to the governor's wife no longer has any hold over him. Azdak proceeds, however, as usual, accepting bribes from the wealthier party, while abusing Grusha (and Simon) who have nothing to offer him: and this is which brings on the first serious opposition he has to encounter. Grusha declares that she has no respect for a judge such as he is, "... no more than for a thief and or a bandit with a knife! You can do what you want" $(V, 203)$.

Grusha has all our sympathy and indeed, we may guess the end of the play: after the so-called trial of the chalk circle in which each woman is to pull at the child from different sides-and Grusha fails to pull for fear of hurting the boy-Azdak ceremonially declares that Grusha is the true mother since she alone has shown true motherly feelings.

This is very obvious: first, it is Azdak's instinctive prompting, that is, a kind of his nature. Secondly, he respects-without thought of argument-the virtue in Grusha. Thus, the fusion of the virtue, that is,
Grusha's human and Azdak's inhuman unpredictability brings about the completion: a sort of temporary solution.

The narrator, through the singer at the end of the last act, says, "... The period of his judging as a brief golden age. Almost an age of justice ... That what there is shall go to those who are good for it ...." Indeed, it is almost an age of justice: not the golden age but a brief golden age, not an age of justice but almost of justice.

\section{Final Remark}

Looking into Brecht's The Caucacian Chalk Circle, we may point out that the two main characters of the play, Grusha and Azdak, are made use by Brecht to practice his epic theater in general, and his Verfremdungseffekt in particular. They are too "estranged" for us to be able to accept them as heroes. Brech, however, manages to highlight the vitality of his central characters.

It is understandable that Speirs in his Bertolt Brecht points out that the tale of Grusha may be said as mainly employing effects of sentiment, heroism-with occasional touches of comedy-to draw the audience into her struggle to behave humanely in a society where the majority of men of all classes are alienated from their own humanity by conflicts of material interest; whereas Azdak's story seems to rely mainly on comedy-with occasional touches of pathos-to evoke sympathy for a rather different, less self-sacrificing approach to the defense of humane values in a hostile world (1987: 167).

Finally, after scrutinizing the play, it is recommended for a further study in the light of Marxism especially regarding, among others, Azdak's behaviour which may be regarded as being dictated at least as much by a human motive as it is by respect for the principles of class-struggle. The study then may be focused and dwelt upon the Marxistbased analysis of social relation. 


\section{Notes}

1 This study uses the text of Brecht's The Caucasian Circe Chalk from the revised English translation by Eric Bentley, Parables for the Theatre, Two Plays by Bertold Brecht (Harmondsworth: Penguin Books Ltd., 1975) 111-207.

2 See Willett, The Theatre 171, for a further elaboration concerning Aristotle's Poetics and that of Schumacher.

3 Eugen Berthold Brecht, who was born on 10 February 1898, was in exile in Denmark, Finland and USA from 1933 to 1947. In 1957 he returned to Europe, and then founded "Berliner Ensemble" in 1949. He died on 14 August 1956.

\section{References}

Bentley, Eric. Parables for the Theatre, Two Plays by Bertold Brecht. Harmondsworth: Penguin Books Ltd., 1975.

Brecht, Bertolt. Brecht on Theater. Ed. and trans. John Willett. London: Methuen London Ltd., 1986.

Counsell, Colin. Signs of Performance: An Introduction to Twentieth-Century Theatre. London and New York: Routledge, 1996.

Ousby, Ian, ed. The Cambridge Guide to Literature in English. Cambridge: Cambridge University Press, 1992.

Speirs, Ronald. Bertold Brecht. London: Macmillan Publishers Ltd., 1987.

Willett, John. The Theatre of Bertolt Brecht: A Study from Eight Aspects. London: Methuen \& Co. Ltd., 1959. 